\title{
Opportunities and Barriers of Practicum from the Perspectives of English Language Student Teachers
}

\author{
Thouqan Saleem Yakoub Masadeh \\ Department of Curriculum and Instruction, Najran University, Saudi Arabia
}

Copyright $(2017$ by authors, all rights reserved. Authors agree that this article remains permanently open access under the terms of the Creative Commons Attribution License 4.0 International License

\begin{abstract}
The study investigated the perspectives of student teachers regarding the opportunities provided by Practicum course, in addition to the barriers that potentially inhibited their performance as teachers. The descriptive approach was used to identify these opportunities and barriers. Participants were (27) females and (31) males. They were all enrolled in the Practicum course offered by the department of curriculum and instruction to students majoring in English at Najran University. A two-part questionnaire was the main instrument of data collection. The first part investigated the opportunities while the second one sought to identify the barriers. Results showed that Practicum course was effective in certain areas such as developing student teachers' supportive relationships with various participants in the Practicum setting; improving their teaching accomplishments and professional achievements; and enhancing their feelings of self-efficacy in being able to affect positively the students under their care. Findings however revealed many shortcomings or obstacles that hindered their performance as teaching practitioners. Such shortcomings were not related to one specific party but many parties such as academic supervisors, school principals, and cooperating teachers. No significant differences among Participants' perspectives regarding the course's opportunities or barriers were found due to their gender or university accumulative average.
\end{abstract}

Keywords Practicum, Student Teachers, Teaching Opportunities, Teaching Barriers, Academic Supervisors, Cooperating Teachers, Najran University

\section{Introduction}

Once nations need to create more progress and achieve prosperity, they should reform their education systems where teachers are the key components. Nevertheless, teachers will not perform their duties as well as required unless they are well-prepared and qualified. Practicum is a university course that equips student teachers with practical knowledge about teaching in real context. It can familiarize them with the teaching process complexity and challenges they may encounter, [1]. In addition, Practicum educates student teachers to interact with actual learners, [2]. It is the student teacher's first hands-on experience with the chosen career. It creates opportunities for students to develop their pedagogical skills. That is, Practicum is the best mean for student teachers to acquire the professional knowledge and competences as teachers, [3]. Teaching, in itself cannot be performed easily. Nevertheless, it is one of the most stressful professions especially in the teachers' first years. Much effort is needed by student teachers and academic supervisors to avoid frustration; make teaching more exciting and shape the future of individuals as well as the future of the entire generations. In order to play their desired roles in this changing and challenging world, teachers should be provided with a range of knowledge, skills, attitudes and relevant educational experiences that empower them to manage all challenges in the teaching profession. Universities are expected to prepare teachers to meet the needs and realities of today's classroom, and highly distinguish their subject matter and methods of teaching, [4]. During Practicum, student teachers' general teaching skills are improved; their attitudes towards learners become more open and their self-esteem and subjective well-being can be increased, [5].

Practicum should take into consideration student teachers' needs and barriers inside school and particularly in the classroom. Involving student teachers in effective teaching practices requires providing them with specialized skills; knowledge of teaching textbook content; effective instructional practices; and assessment practices, [6]. During the practicum period, student teachers are expected to be educated to prepare, plan, teach and interact with school students and teachers within their day-to-day activities, [7]. Practicum, all over the world and more specifically in Saudi universities, involves theoretical as well as practical components. The teaching practice represents the practical aspect of Practicum. It usually takes place during the students' last semester at the university and often lasts for the whole school term or at least (14-16) weeks. Cognitive and 
psychological dimensions are included in such a course. The lesson observation, cooperating teacher, academic supervisor, interaction with members at other schools, and peer teachers are the most beneficial sources for student teachers to improve, [16]. When evaluating the performance of student teachers, academic supervisors usually depend on a set of subject-specific rubrics that assess planning, instruction, assessment, reflection, and academic language. They do not think about the challenges and obstacles that student teachers face in real contexts and so stress, anxiety and dissatisfaction among them are generated causing them to perform poorly, [12].

In short, Practicum is the actual opportunity for university students to be successful teachers if well implemented. Student teachers are the main beneficiaries and so their perceptions are the most important. The ultimate goal of identifying their conceptions is to understand how they view Practicum, its character, and purpose. School-based teaching practice is the most important component of training, because of the actual teaching and learning opportunities. It works as an essential bridge between theory and practice. It is the real opportunity to define and refine teaching skills, [8]. Cooperating teachers and academic supervisors are the most important sources of practical experience for student teachers because they work as supervisors, mentors, observers, model teachers, and supporters for them, [9].

\subsection{Related Work}

Many researches have been conducted to address ways for making Practicum more enjoyable and worthwhile. Many studies have been implemented to discuss, explain, support, and understand student teachers' perceptions in accordance to the benefits and barriers of Practicum course. For instance, [10] showed that the cooperating teachers' enthusiasm and friendliness encouraged student teachers to begin their experience active and hopeful. Cooperating teachers were helpful in familiarizing student teachers with the use of the whiteboard, pointer and chalk. They educated them how to implement their lessons in the classrooms. They could also provide significant help to apply theoretical assumptions into lesson planning and explaining. Whereas, their inability to help in the teaching techniques, feedback provision, guidance in co-curricular activities and classroom discipline and management were the most important barriers that hindered their performance. [11] showed that student teachers' experience was not as desired because of a set of barriers like the fact that Practicum program was not well prepared. Student teachers had no means of transportation to commute from university to schools and no manuals were prepared. The academic supervisor on the other hand, was allotted many students, and he did not use multi-references to assess his students' performance, attendance, lesson planning, reports and class demonstration. Cooperating teachers did not offer training or model lesson plans. They did not regularly observe and comment on trainees' performance in the classroom because their experience was insufficient to deal with student teachers and run the training program. Furthermore, school principals did not follow up student teachers' lesson plans, as it is the task that none can do it except themselves. Student teachers in [12] reported that means of assessing their lessons planning and general organization were very effective. The way by which the academic supervisors evaluated their performance was very appropriate, too. However, means of assessment used by their cooperating teachers were ineffective. Cooperating teachers' ways of writing observation and reflection reports were not skillful. Peer teachers' evaluation was the least effective component. [4] found out that the gap between theory and practice, i.e. between what was learnt at university and what was actually practiced at school, was another barrier for student teachers' success. The lack of necessary facilities that should be provided by cooperating schools and the short time they spent at schools were also seen as important hindrances. Results of [13] showed that student teachers evaluated highly the role of their academic supervisors in their success in Practicum. Academic supervisors as reported by students served as role models and were keen to care personally about them. Besides, the relationship with cooperating teachers was an important factor that could produce negative or positive placement. The most important barriers were their feeling unprepared to manage classrooms. The lack of practical focus in teacher education courses had a negative effect on their self-efficacy. Class size was also a major obstacle. Results of [3] indicated an urgent need for explicit criteria that had better define effective teaching. Lesson observation was a two-way road. While it serves as a test, it was a means for reflection and professional development.

[14] argues that the challenge mostly student teachers faced with is whether or not they are able to translate theoretical knowledge at university to actual experience at the classrooms. Cooperating teachers play a significant role in doing so by shaping what those student teachers have explored in theory. Therefore, it was essential to use participatory dialogues throughout Practicum to support student teachers' performance in classroom. [15] revealed that student teachers needed more help on how to integrate terminology and language use in Practicum. Academic supervisors and cooperating teachers should help student teachers understand themselves as teachers. They can show them what expectations they should fulfill, how to understand the curriculum they are teaching, and how to manage their classes. [16] reported that student teachers had rich interactions with their cooperating teachers, academic supervisors and other school members. Lesson observation, mentoring of cooperating teachers, supervision of academic supervisors and communication with other school members and peer classmates were mostly helpful. [2] concluded that 
academic supervisors, cooperating teachers and school principals are responsible for correcting student teachers' misconceptions about teaching practice. Academic supervisors have to emphasize different aspects of student teaching without potential confusion and avoid assessment-focused supervision that negatively affects student teacher's learning. Supervisors' lack of expertise creates fear and desire to conform with student teachers. Poor coordination between universities and schools regarding the content of university course books and school textbooks often confuses student teachers. [9] found no significant differences among student teachers' perceptions due to gender, type of graduation school, type of cooperating school and number of student teachers in the supervisory group. Nevertheless, the moral support provided by cooperating teachers was highly appreciated while the facilitation of the cooperating teachers was the least evaluated opportunity. [17] showed that the lack of the interpersonal relationships with people in the schools like teachers and school staff was the most critical problem for student teachers. The absence of the pedagogical skills and work ethics besides the cooperating teachers' lack of professionalism and support, conflict between practice and reality and their own lack of maturity and experience were also major problems. [18] showed that student teachers were not satisfied with the level and kind of feedback cooperating teachers provided saying that it was the minimum feedback. Participants complained about the shortness and insufficiency of the class observation time for follow up actions. In addition, the minimal interaction with the academic supervisors deprive them being good teachers.

In short, much of the related literature has asserted the fact that there are specific issues in Practicum playing significant roles in the success or failure of prospective teachers. Student teachers' own perceptions according to the opportunities and barriers they experienced during their Practicum are very important. To train someone to perform a job means that you should provide him/her with all success means and overcome all difficulties he/she is expected to encounter. Practicum coordinators should foster all positive points and have control over all negative and problematic areas. [19] mentions that traditional Practicum represented in class visits, planning, attendance, punctuality and class management is not sufficient. New Practicum should incorporate some structural opportunities that help student teachers reflect on their learning. Cooperating teachers and supervisors are to be supportive. i. e. facilitators not hinderers. In short, Practicum is the solo course that trains student teachers to practice various teaching activities in real contexts like, for instance preparing well daily and long-term plans; managing classroom; using teaching strategies and aids; interacting with school students; evaluating students' learning; having positive attitudes towards the profession and students; and identifying and respecting the laws and regulations of the teaching profession. Hence, the present study will survey the perceptions of student teachers' regarding the most important segments in Practicum and namely, cooperating teachers, school principals and academic supervisors.

\subsection{Significance of the Study}

Practicum is the component of university-based social work education that is most crucial for the development of practice-based skills and socializing students into the professional role, [20]. The breadth of learning that occurs in Practicum and the diversity of practice challenges and learning opportunities are perhaps the most difficult aspects to evaluate in this component, [21]. According to the sociocultural theories, knowledge entails accumulated information as well as lived practices. Learning processes are often negotiated with people regarding what they do through experiences in the social practices associated with particular activities [22:273]. Student teachers should learn to do their work through situated engagement and negotiation with practitioners and peers in teaching community. They should realize what it means to be a teacher through the observation and communication with academic supervisors, cooperating teachers and peers. Consequently, their relations with all these parties will affect their perceptions about teaching profession and enhance or hinder their teaching practice as successful teachers. Therefore, the in advance identification of the opportunities these students will gain and the barriers they will encounter during the period of Practicum might make Practicum more interesting and beneficial for all. People in charge at university and education directorates should be more aware of and more cooperative to enhance the opportunities and overcome the barriers. That is, findings of the present study can be considered worthy for decision makers to modify the way Practicum is implemented at schools. Student teachers can also be more conscious of what they are going to encounter at schools while the roles of the academic supervisors can be more significant in the process of educating student teachers.

\subsection{Questions of the Study}

The present study aims to answer these questions:

1. What are the most important opportunities of English language Practicum as perceived by student teachers at Najran University?

2. What are the most important barriers of English language Practicum as perceived by student teachers at Najran University?

3. Is there any statistically significant difference in student teachers' perceptions regarding the opportunities of English language Practicum due to their gender?

4. Is there any statistically significant difference in student teachers' perceptions regarding the barriers of English language Practicum due to their gender?

5. Is there any statistically significant difference in student teachers' perceptions regarding the 
opportunities of English language Practicum due to their accumulative averages?

6. Is there any statistically significant difference in student teachers' perceptions regarding the barriers of English language Practicum due to their accumulative averages?

\section{Methodology}

\subsection{Study Approach}

The present study followed the descriptive approach, which is usually used to obtain information concerning the status of the phenomena to describe what exists with respect to variables or conditions in a certain situation. By a descriptive approach, quantifiable information about study participants can be gathered and used for statistical inference through data analysis. It can help the researcher better define and measure the significance of something about a group of respondents and the population they represent.

\subsection{Participants}

All students enrolled in Practicum course (431 Curriculum 8) offered by the department of curriculum and instruction students at the department of English language at Najran University in the first semester of 2016-2017 were enrolled in the present study. Their total number was (58) among them were (27) males and (31) females. Student teachers' perceptions constituted the dependent variable while gender and accumulative average were the study independent variables. Table 1 shows the distribution of participants according to gender and accumulative average.

\subsection{Data Collection Instrument}

A Student Teachers' Perception Questionnaire (STPQ) consisting of thirty-one (31) items was developed to collect the study data. The questionnaire consisted of three sections namely, personal information, student teachers' perceptions about the opportunities they achieved throughout the Practicum course, and the barriers they encounter while carrying out their teaching practice at schools. Five responses were attached to each item mainly Strongly agree, Agree, Neutral, Disagree, and Strongly Disagree. Responses were assigned $(5,4,3,2, \& 1)$ respectively. Means from $(1.20-2.00)$ represent strongly disagree, $(2.01-2.80)$ stand for disagree, (2.81-3.60) indicate Neutral, (3.61 - 4.20) represent agree, and (4.21-5.00) express the strongly agree level.

\subsection{Validity and Reliability of STPQ}

Six experts at the department of curriculum and instruction at the college of education, Najran University were requested to check the content validity of the questionnaire. Their academic ranks ranged from assistant professor to professor doctor. The instrument was tested in a pilot sample of ten (10) students. Reliability coefficient was calculated by using Cronbach Alpha and was (0.906). This was an indication that the questionnaire was within the acceptable threshold in social sciences and fit to be used to gather data for the present study. During data analysis, responses in all questionnaires were coded, scored and then analyzed using both descriptive statistics (means and standard deviations) and inferential t-test statistics.

\subsection{Data Collection and Analysis}

The questionnaire was administered to all study participants by the researcher himself, as it was easy to contact all of them at the end of the semester. The collected data were re-analyzed, in terms of participants' gender and accumulative averages at university. (SPSS) program was used for the analysis, while T-test was used to find out whether these variables affected significantly the responses of the student teachers.

Table 1. Distribution of Study Participants according to Study Variables

\begin{tabular}{|c|c|c|c|c|c|}
\hline & & Accumulative Average at University & $\mathbf{N}$ & Category & $\mathbf{N}$ \\
\hline \multirow{8}{*}{ Gender } & \multirow{4}{*}{ Male (N=27) } & Excellent & 10 & \multirow{2}{*}{ High } & \multirow{2}{*}{20} \\
\hline & & Very good & 10 & & \\
\hline & & Good & 3 & \multirow{2}{*}{ Low } & \multirow{2}{*}{7} \\
\hline & & Average & 4 & & \\
\hline & \multirow{4}{*}{ Female $(\mathrm{N}=31)$} & Excellent & 6 & \multirow{2}{*}{ High } & \multirow{2}{*}{23} \\
\hline & & Very good & 17 & & \\
\hline & & Good & 7 & \multirow{2}{*}{ Low } & \multirow{2}{*}{8} \\
\hline & & Average & 1 & & \\
\hline \multicolumn{2}{|c|}{ Total Number } & & 58 & & 58 \\
\hline
\end{tabular}




\section{Findings}

\subsection{Findings Related to the First Question}

To answer the first question that aimed to determine the most important opportunities of English language Practicum as perceived by student teachers at Najran University, means and standard deviations were extracted for all participants' responses. Results are shown in table 2 below.

Table 2 reflects student teachers' beliefs of the ability of Practicum course to provide them with a set of opportunities. The general mean of their agreement was (4.34) indicating a strongly agree degree. The most important opportunity $(M=4.74)$ was the course's help to diversify their teaching strategies and methods. In the second rank was the increase of their knowledge and appreciation of school laws and regulations $(\mathrm{M}=4.69)$ followed by generating their self-satisfaction $(\mathrm{M}=4.57)$. The identification of the most appropriate skills of classroom management $(\mathrm{M}=4.55)$ were in the fourth and fifth ranks. The opportunities to test and explore the effect of their characters when dealing with others $(\mathrm{M}=4.47)$, the distinction of the most necessary and appropriate skills for the teaching process $(\mathrm{M}=4.41)$ and the improvement of their knowledge of working and cooperating with others $(M=4.41)$ were also of much importance. The least important opportunities provided by Practicum, as was revealed by students' responses were the development of their communication skills with their students' parents $(\mathrm{M}=4.03)$ and the opportunity to try preparing daily and quarterly planning $(\mathrm{M}=2.21)$.

Table 2. Means and standard deviations of participants' responses regarding Practicum opportunities

\begin{tabular}{|c|c|c|c|}
\hline No & Student teachers' perspectives of Practicum opportunities (males and females). ( $N=58$ ) & M. & Agreement level \\
\hline 1. & Practicum helped me to diversify my teaching strategies and methods. & 4.74 & S. agree \\
\hline 2. & Practicum increased my knowledge and appreciation of the school laws and regulations. & 4.69 & S. agree \\
\hline 3. & Practicum generated my self-satisfaction. & 4.59 & S. agree \\
\hline 4. & Practicum enabled me to practice the teaching profession in real context. & 4.57 & S. agree \\
\hline 5. & Practicum helped me to identify the appropriate skills of classroom management. & 4.55 & S. agree \\
\hline 6. & Practicum enabled me to explore the effect of my character when dealing with others. & 4.47 & S. agree \\
\hline 7. & Practicum enabled me to distinguish the most necessary and appropriate skills for teaching. & 4.41 & S. agree \\
\hline 8. & Practicum improved my knowledge of working and cooperating with others. & 4.41 & S. agree \\
\hline 9. & Practicum developed my communication skills with colleagues. & 4.38 & S. agree \\
\hline 10. & Practicum enhanced my way of working and cooperating with others. & 4.33 & S. agree \\
\hline 11. & Practicum made me aware of the necessary and appropriate facilities and means for teaching. & 4.28 & S. agree \\
\hline 12. & Practicum helped me to prepare educational software that supports teaching. & 4.28 & S. agree \\
\hline 13. & Practicum showed me the teaching knowledge and skills. & 4.22 & S. agree \\
\hline 14. & Practicum developed my communication skills with parents of the students. & 4.03 & Agree \\
\hline 15. & Practicum trained me to prepare the daily/quarterly planning. & 3.21 & Agree \\
\hline \multicolumn{2}{|r|}{ General mean } & 4.34 & S. agree \\
\hline
\end{tabular}




\subsection{Findings Related to the Second Question}

To answer the second question that aimed to determine the most important barriers of English language Practicum as perceived by student teachers at Najran University, means and standard deviations were calculated for all participants' responses. Table 3 illustrates the results.

Table 3 presents the shortcomings that have played a significant role in inhibiting student teachers to be effective and successful. Their evaluation of the shortcoming as a whole $(\mathrm{M}=3.09)$ reflects their dissatisfaction with the help offered by their academic supervisor, cooperating teacher and school principal. Their responses indicate that they had not found the amount of help they expected from these three parts. The most important shortcomings they mentioned were the absence of school principals' follow up of their lesson plan notebooks $(\mathrm{M}=2.50)$ and the lack of purposeful workshops that focus on training them how to use teaching aids in the classroom $(\mathrm{M}=2.52)$. The fact that various courses at university do not qualify them to teach appropriately $(\mathrm{M}=2.62)$ was another shortcoming that made their task somehow difficult. Their inability to contact and communicate with their cooperating teachers $(\mathrm{M}=2.76)$ and to receive their helpful feedback $(\mathrm{M}=2.86)$ were other serious shortcomings that could hinder their teaching practice progress. The inefficiency of cooperating teacher to cope with student teachers and train them $(\mathrm{M}=2.86)$ was another critical problem for student teachers' teaching practice. Their views regarding the sufficiency of workshops conducted at university to discuss key issues related to teaching $(\mathrm{M}=2.97)$ indicated their low satisfaction level with the way by which they were prepared at university. The awareness of cooperating teachers to facilitate the teaching process and make teaching fun (2.98) showed their inability to be supervisors who were assumed to ease student teachers task. Furthermore, Academic supervisors' weekly orientation was not enough to help student teachers be good teachers $(\mathrm{M}=2.98)$. Academic supervisors' proper explanation of required tasks for Practicum $(\mathrm{M}=2.26)$, their encouragement to student teachers' to ask various to develop their skills $(\mathrm{M}=3.38)$ and the clarity of tasks to accomplished during Practicum $(\mathrm{M}=3.50)$ had better evaluation but still cause problems for student teachers and should be reconsidered. Nevertheless, student teachers expressed a good level of satisfaction regarding the solutions proposed by academic supervisors to solve their problems $(\mathrm{M}=3.60)$ and a very high level of conviction with respect to the fair evaluation they had at the end of the course $(M=4.43)$.

Table 3. Means and standard deviations of participants' responses regarding Practicum barriers

\begin{tabular}{|c|l|c|c|}
\hline No. & Student teachers' perceptions of Practicum barriers (males and females) (N=58) & M & Agreement level \\
\hline 1. & The school principal always asked for lesson plan notebook. & 2.50 & Disagree \\
\hline 2. & Training workshops focus on how to use teaching aids in the classroom. & 2.52 & Disagree \\
\hline 3. & The various courses taught at university prepare student teachers to teach appropriately. & 2.62 & Disagree \\
\hline 4. & $\begin{array}{l}\text { It was easy to communicate with my cooperating teacher when I needed any explanation regarding } \\
\text { teaching. }\end{array}$ & 2.76 & Neutral \\
\hline 5. & Feedback of my cooperating teacher was very helpful during Practicum. & 2.86 & Neutral \\
\hline 6. & My cooperating teacher was competent to deal with student teachers and run the training program. & 2.97 & Neutral \\
\hline 7. & The workshops at college for discussing teaching key issues were sufficient. & 2.98 & Neutral \\
\hline 8. & The cooperating teacher facilitated the teaching process and made it fun for me. & 2.98 & Neutral \\
\hline 9. & My academic supervisor specified in advance the topics to be discussed each week. & 3.26 & Neutral \\
\hline 10. & My academic supervisor explained properly the tasks required for Practicum properly. & 3.38 & Neutral \\
\hline 11. & My academic supervisor encouraged me to ask questions that could help me develop my various skills. & 3.50 & Neutral \\
\hline 12. & The required tasks that I had to accomplish during the Practicum were quite clear. & 3.60 & Agree \\
\hline 13. & My academic supervisor used to suggest solutions to my problems. & 3.43 & S. agree \\
\hline 14. & The method of evaluating my skills in the Practicum was fair and appropriate. & Neutral \\
\hline & & General Mean & 3.09 \\
\hline
\end{tabular}


Table 4. A comparison between male and female participants' responses regarding Practicum opportunities

\begin{tabular}{|c|c|c|c|c|c|}
\hline No. & $\begin{array}{l}\text { Male student teachers' means compared with female student } \\
\text { teachers' means with respect to Practicum opportunities }\end{array}$ & $\begin{array}{l}\text { Males } \\
\mathbf{N}=27\end{array}$ & Agreement level & $\begin{array}{c}\text { Females } \\
\mathbf{N}=\mathbf{3 1}\end{array}$ & Agreement level \\
\hline 1. & $\begin{array}{l}\text { Practicum increased my knowledge and appreciation of the } \\
\text { school laws and regulations. }\end{array}$ & 4.89 & S. agree & 4.52 & S. agree \\
\hline 2. & $\begin{array}{l}\text { Practicum helped me to diversify my teaching strategies and } \\
\text { methods. }\end{array}$ & 4.93 & S. agree & 4.58 & S. agree \\
\hline 3. & $\begin{array}{l}\text { I could identify the necessary and appropriate facilities and } \\
\text { means for teaching in a timely manner }\end{array}$ & 4.85 & S. agree & 3.77 & Agree \\
\hline 4. & $\begin{array}{l}\text { Practicum helped me to prepare educational software that support } \\
\text { teaching. }\end{array}$ & 4.59 & S. agree & 4.00 & Agree \\
\hline 5. & $\begin{array}{l}\text { I could distinguish the most necessary and appropriate skills for } \\
\text { the teaching process. }\end{array}$ & 4.67 & S. agree & 4.19 & Agree \\
\hline 6. & $\begin{array}{l}\text { I could practice the teaching profession, as a result of the well } \\
\text { Practicum }\end{array}$ & 4.78 & S. agree & 4.39 & S. agree \\
\hline 7. & Practicum generated my self-satisfaction, esteem and confidence. & 4.63 & S. agree & 4.55 & S. agree \\
\hline 8. & $\begin{array}{l}\text { Practicum enhanced, fostered and improved my teaching } \\
\text { experience. }\end{array}$ & 4.85 & S. agree & 3.87 & Agree \\
\hline 9. & $\begin{array}{l}\text { I could benefit from the cooperating teacher's good teaching } \\
\text { knowledge and skills. }\end{array}$ & 4.74 & S. agree & 3.77 & Agree \\
\hline 10. & $\begin{array}{l}\text { I could learn how to work and cooperate with others during } \\
\text { Practicum }\end{array}$ & 4.85 & S. agree & 4.03 & Agree \\
\hline 11. & $\begin{array}{l}\text { Through "Practicum", I learned the adequate preparation of } \\
\text { daily/quarterly plans }\end{array}$ & 2.52 & Disagree & 3.81 & Agree \\
\hline 12. & $\begin{array}{l}\text { During "Practicum", I could acquire the appropriate skills of } \\
\text { classroom management. }\end{array}$ & 4.78 & S. agree & 4.35 & S. agree \\
\hline 13. & Practicum developed my communication skills with colleagues & 4.67 & S. agree & 4.13 & Agree \\
\hline 14. & $\begin{array}{l}\text { Practicum allowed me to test and explore the effect of my } \\
\text { character when dealing with others. }\end{array}$ & 4.52 & S. agree & 4.42 & S. agree \\
\hline 15. & $\begin{array}{l}\text { Practicum developed my communication skills with parents of } \\
\text { the students }\end{array}$ & 4.74 & S. agree & 3.42 & Neutral \\
\hline \multicolumn{2}{|r|}{ General Mean } & 4.60 & S. agree & 4.12 & Agree \\
\hline
\end{tabular}

\subsection{Findings Related to the Third Question}

To answer the third question that aimed to test whether student teachers' perceptions regarding Practicum opportunities vary according to their gender, a comparison between the means of their responses was made. Table 4 presents the results.

Table 4 presents a comparison between the means of male and female student teachers with regard to their evaluation of the benefits they have gained during their field experience. A strong agreement was found on some areas like the program's ability to increase student teachers' knowledge and appreciation of school laws and regulations and to train them to try various teaching strategies and methods. In addition, Practicum was very effective in training them to practice teaching profession in real contexts, to generate their self- satisfaction, esteem and confidence. Moreover, student teachers' responses indicate that because of Practicum, they could acquire the most suitable skills of classroom management and they could test and explore the effect of their characters when dealing with others.
Nevertheless, a discrepancy in their views regarding some areas was revealed. As shown in table 4 a disagreement between male and female student teachers' perceptions can be noticed. Males' agreement was stronger than females' agreement with respect to the issues of the identification of necessary and appropriate facilities and means for teaching in a timely manner, the development of their abilities to prepare educational software that support teaching and the distinction of the most necessary and appropriate skills for the teaching process. Moreover, female student teacher' responses indicate that Practicum could not develop their teaching practice, help them to benefit from the cooperating teacher, provide them with effective ways to work and cooperate with others and enable them to communicate with their colleagues at schools and parents of their students as well as it did to male ones. However, both participant groups' responses indicated that Practicum could develop females' skills in planning and daily/quarterly preparation much better than it did to males' skills. T. test was carried out to check whether there is a significant difference between both participant groups. Findings are shown in table 5.

Table 5. T. Test for the difference between males and females regarding Practicum opportunities

\begin{tabular}{|c|c|c|c|c|c|c|}
\hline Group & N & M & SD & Mean Difference & T. Ratio & Sig. \\
\hline Male student teachers & 27 & 4.60 & 0.58725 & 0.48 & 2.728 & 0.998 \\
\hline Female student teachers & 31 & 4.12 & 0.34779 & & & \\
\hline
\end{tabular}


Table 5 reveals no statistically significant difference between male and female student teachers in accordance to the benefits they have got because of their Practicum or field experience. Therefore, it can be inferred that both views are congruent. Student teachers whether males or females were aware of and in the same time appreciated highly these opportunities.

\subsection{Findings Related to the fourth Question}

To answer the fourth question that aimed to test whether student teachers' perceptions regarding Practicum barriers vary according to their gender, a comparison between the means of their responses was made. Table 6 presents the results.

As shown in table 6, there was mostly an agreement between males $(\mathrm{M}=2.95)$ and females $(\mathrm{M}=3.14)$ with regard to the barriers and shortcomings of Practicum that affected their teaching performance. Most of their agreement levels ranged between "disagree, neutral or cannot decide" indicating their dissatisfaction with certain actions and arrangements during their field experience that could deprive them from being successful teachers and caused a loss of experience. Nevertheless, means revealed a disagreement between their views regarding the clarity of tasks that they should implement during Practicum Male participants $(\mathrm{M}=2.33)$ were less satisfied with this fact than females $(\mathrm{M}=3.65)$. T. test was implemented to check whether there was a significant difference between both participant groups. Findings are shown in table 7.

Once again, table 7 indicates no statistically significant difference between male and female student teachers with regard to the shortcomings they experienced and were affected by during their Practicum or field experience. Both participant groups' responses asserted the same difficulties and so it could be inferred that these problems were common and apparent.

Table 6. A comparison between male and female participants' responses regarding Practicum barriers

\begin{tabular}{|c|c|c|c|c|c|}
\hline No. & $\begin{array}{l}\text { Means of male and female student teachers' responses to the } \\
\text { barriers of "Practicum" }\end{array}$ & $\begin{array}{l}\text { Male } \mathbf{N}= \\
27\end{array}$ & Agreement level & $\begin{array}{c}\text { Females } \\
\mathbf{N}=\mathbf{3 1}\end{array}$ & Agreement level \\
\hline 1. & $\begin{array}{l}\text { My academic supervisor specified in advance the topics to be } \\
\text { discussed each week. }\end{array}$ & 2.96 & Neutral & 3.00 & Neutral \\
\hline 3. & $\begin{array}{l}\text { It was easy to communicate with my cooperating teacher when I } \\
\text { needed any explanation regarding teaching. }\end{array}$ & 2.22 & Disagree & 3.23 & Neutral \\
\hline 5. & $\begin{array}{l}\text { The required tasks that I had to accomplish during the Practicum } \\
\text { were quite clear. }\end{array}$ & 2.33 & Disagree & 3.65 & Agree \\
\hline 6. & $\begin{array}{l}\text { The workshops at college for discussing teaching key issues were } \\
\text { sufficient. }\end{array}$ & 2.93 & Neutral & 3.00 & Neutral \\
\hline 7. & $\begin{array}{l}\text { Training workshops focus on how to use teaching aids in the } \\
\text { classroom. }\end{array}$ & 2.85 & Neutral & 2.23 & Disagree \\
\hline 9. & The school principal always asked for lesson plan notebook. & 2.11 & Disagree & 2.84 & Neutral \\
\hline 10. & $\begin{array}{l}\text { My academic supervisor used to suggest solutions to my } \\
\text { problems }\end{array}$ & 3.63 & Agree & 3.58 & Neutral \\
\hline 11. & $\begin{array}{l}\text { I was encouraged to ask questions that could help me develop my } \\
\text { various skills }\end{array}$ & 3.63 & Agree & 3.16 & Neutral \\
\hline 12. & $\begin{array}{l}\text { The cooperating teacher facilitated the teaching process and } \\
\text { made it fun for me. }\end{array}$ & 2.78 & Disagree & 3.16 & Neutral \\
\hline 13. & $\begin{array}{l}\text { The method of evaluating my skills in the Practicum was fair and } \\
\text { appropriate }\end{array}$ & 4.85 & S. agree & 4.06 & Agree \\
\hline 14. & $\begin{array}{l}\text { Feedback of my cooperating teacher was very helpful during } \\
\text { Practicum }\end{array}$ & 2.96 & Neutral & 2.77 & Neutral \\
\hline \multicolumn{2}{|r|}{ General Mean } & 2.95 & & 3.14 & Neutral \\
\hline
\end{tabular}

Table 7. T. Test for the difference between males and females regarding Practicum obstacles

\begin{tabular}{|c|c|c|c|c|c|c|}
\hline Group & $\mathbf{N}$ & M & SD & Mean Difference & T. Ratio & Sig. \\
\hline Male student teachers & 27 & 2.9514 & 0.70905 & 0.1914 & 0.850 & 0.413 \\
\hline Female student teachers & 31 & 3.1429 & 0.45544 & & & \\
\hline
\end{tabular}




\subsection{Findings Related to the Fifth Question}

To answer the fifth question that aimed to test whether student teachers' perceptions regarding Practicum opportunities vary according to their university accumulative average, a comparison between the means of their responses was made. Table 8 presents the results.

Table 8 presents a comparison between the means of student teachers of high and low accumulative averages at university in accordance to the benefits of Practicum. A very strong agreement between both participant groups was noticed on nearly most of the benefits Practicum offers. Means were ranging from "agree to strongly agree". Only the benefit that revolved about training them to prepare and plan their lessons, whether daily or quarterly was not satisfactory for both and fell in "neutral or can't decide" category. However, a disagreement between students of high and low accumulative averages was revealed with respect to the amount of benefit they got of the cooperating teachers' knowledge and skills. In addition, high average students reported their strong agreement on Practicum's ability to equip them with skills by which they could cope, cooperate and communicate with others, whether colleagues or others. Low average students showed an agreement but not too strong regarding these issues. T. test was used to check whether there was a significant difference between both participant groups. Table 9 presents the finding.

As shown in table 9, there was no statistically significant difference between the perceptions of student teachers whether their accumulative average at university is high or low. Both participant groups understood what advantages they have gained through practicing teaching in real contexts. That is, Practicum helped student teachers in moderate degrees and so all of them have benefited much despite their high or low accumulative averages.

Table 8. A comparison between participants' high and moderate university accumulative averages regarding Practicum opportunities

\begin{tabular}{|c|c|c|c|c|c|}
\hline No & $\begin{array}{l}\text { Means of male and female student teachers' responses to } \\
\text { the opportunities of "Practicum" }\end{array}$ & $\begin{array}{c}\text { High } \\
\text { average } \\
\mathrm{N}=43\end{array}$ & Agreement level & $\begin{array}{c}\text { Low } \\
\text { average } \\
N=15\end{array}$ & Agreement level \\
\hline 1. & $\begin{array}{l}\text { Practicum increased my knowledge and appreciation of the } \\
\text { school laws and regulations }\end{array}$ & 4.72 & S. agree & 4.60 & S. agree \\
\hline 2. & $\begin{array}{l}\text { Practicum helped me to diversify my teaching strategies and } \\
\text { methods }\end{array}$ & 4.77 & S. agree & 4.67 & S. agree \\
\hline 3. & $\begin{array}{l}\text { I could identify the necessary and appropriate facilities and } \\
\text { means for teaching in a timely manner }\end{array}$ & 4.35 & S. agree & 4.07 & Agree \\
\hline 4. & $\begin{array}{l}\text { Practicum helped me to prepare educational software that } \\
\text { support teaching. }\end{array}$ & 4.23 & S. agree & 4.40 & S. agree \\
\hline 5. & $\begin{array}{l}\text { I could distinguish the most necessary and appropriate skills } \\
\text { for the teaching process. }\end{array}$ & 4.42 & S. agree & 4.40 & S. agree \\
\hline 6. & $\begin{array}{l}\text { I could practice the teaching profession, as a result of the well } \\
\text { "Practicum" }\end{array}$ & 4.53 & S. agree & 4.67 & S. agree \\
\hline 7. & Practicum generated self-satisfaction within me. & 4.58 & S. agree & 4.60 & S. agree \\
\hline 8. & $\begin{array}{l}\text { Practicum enhanced, fostered and improved my teaching } \\
\text { experience. }\end{array}$ & 4.35 & S. agree & 4.27 & S. agree \\
\hline 9. & $\begin{array}{l}\text { I could benefit from the cooperating teacher's good teaching } \\
\text { knowledge and skills. }\end{array}$ & 4.26 & S. agree & 4.13 & Agree \\
\hline 10. & $\begin{array}{l}\text { I could learn how to work and cooperate with others during } \\
\text { Practicum }\end{array}$ & 4.53 & S. agree & 4.07 & Agree \\
\hline 11. & $\begin{array}{l}\text { Through Practicum, I learned the adequate preparation of } \\
\text { daily/quarterly plans }\end{array}$ & 3.30 & Neutral & 2.93 & Neutral \\
\hline 12. & $\begin{array}{l}\text { During Practicum, I could learn the appropriate skills of } \\
\text { classroom management. }\end{array}$ & 4.56 & S. agree & 4.53 & S. agree \\
\hline 13. & $\begin{array}{l}\text { Practicum developed my communication skills with } \\
\text { colleagues }\end{array}$ & 4.51 & S. agree & 4.00 & agree \\
\hline 14. & $\begin{array}{l}\text { Practicum allowed me to test and explore the effect of my } \\
\text { character when dealing with others. }\end{array}$ & 4.56 & S. agree & 4.20 & S. agree \\
\hline 15. & $\begin{array}{l}\text { Practicum developed my communication skills with parents } \\
\text { of the students }\end{array}$ & 4.07 & Agree & 3.93 & Agree \\
\hline \multicolumn{2}{|r|}{ General Mean } & 4.38 & S. agree & 4.23 & S. agree \\
\hline
\end{tabular}

Table 9. T. Test for the difference between students of high and low accumulative averages in accordance to Practicum opportunities

\begin{tabular}{|c|c|c|c|c|c|c|}
\hline Group & N & M & SD & Mean Difference & T. Ratio & Sig. \\
\hline High accumulative average & 43 & 4.3827 & 0.35225 & 0.1513 & 1.040 & 0.481 \\
\hline low accumulative average & 15 & 4.2313 & 0.43959 & & & \\
\hline
\end{tabular}




\subsection{Findings Related to the Sixth Question}

To answer the sixth question that aimed to test whether student teachers' perceptions regarding Practicum opportunities vary according to their university accumulative average, a comparison between the means of their responses was made. Table 10 presents.

As shown in table 10, there is an approximate agreement on the barriers of Practicum between students of high university accumulative averages $(\mathrm{M}=2.145)$ and their peers whose university accumulative averages were low $(\mathrm{M}=2.904)$. Student teachers in both groups emphasized these shortcomings nearly in the same degree. Shortcomings like the fact that courses taught at university qualify student teachers to practice teaching appropriately and the fact that school principals do their jobs well to follow up students' lesson plan notebooks were the worst shortcomings that were revealed by student teachers' responses. Both participants showed a very high-level agreement on the fact that the evaluation method used to evaluate their skills was fair and appropriate and so it was not a barrier in front of their teaching practice. Means were (4.42) for males and (4.27) for females. T. test was used to check whether there was a significant difference between both participant groups. Table 11 presents the findings.

Table 11 shows that there was no statistically significant difference between the perceptions of student teachers regarding the barriers due to high or low accumulative average at university. Both participant groups stressed the barriers that have encountered them during their field experience. That is, Practicum could have helped them to be better and more successful teachers if such barriers were eliminated and overcome.

Table 10. A comparison between participants' high and low university accumulative averages regarding Practicum obstacles

\begin{tabular}{|c|c|c|c|c|c|}
\hline No & $\begin{array}{l}\text { Means of male and female student teachers' responses to } \\
\text { the obstacles of "Practicum" }\end{array}$ & $\begin{array}{c}\text { High } \\
\text { average } \\
\mathrm{N}=43\end{array}$ & Agreement level & $\begin{array}{c}\text { Low } \\
\text { average } \\
\mathrm{N}=15\end{array}$ & Agreement level \\
\hline 1. & $\begin{array}{l}\text { My academic supervisor specified in advance the topics to be } \\
\text { discussed each week. }\end{array}$ & 3.21 & Neutral & 2.33 & Disagree \\
\hline 2. & $\begin{array}{l}\text { The various courses taught at university qualify student } \\
\text { teachers to teach appropriately. }\end{array}$ & 2.67 & Disagree & 2.47 & Disagree \\
\hline 3. & $\begin{array}{l}\text { It was easy to communicate with my cooperating teacher when } \\
\text { I needed any explanation regarding teaching. }\end{array}$ & 2.95 & Neutral & 2.20 & Disagree \\
\hline 4. & $\begin{array}{l}\text { My academic supervisor explained properly the tasks required } \\
\text { for Practicum properly. }\end{array}$ & 3.44 & Neutral & 2.73 & Disagree \\
\hline 5. & $\begin{array}{l}\text { The required tasks that } \mathrm{I} \text { had to accomplish during the } \\
\text { Practicum were quite clear. }\end{array}$ & 3.51 & Neutral & 3.47 & Neutral \\
\hline 6. & $\begin{array}{l}\text { The workshops at college for discussing teaching key issues } \\
\text { were sufficient. }\end{array}$ & 2.91 & Neutral & 3.13 & Neutral \\
\hline 7. & $\begin{array}{l}\text { Training workshops focus on how to use teaching aids in the } \\
\text { classroom. }\end{array}$ & 2.37 & Disagree & 2.93 & Neutral \\
\hline 8. & $\begin{array}{l}\text { My cooperating teacher was competent to deal with student } \\
\text { teachers and run the training program }\end{array}$ & 2.93 & Neutral & 2.67 & Disagree \\
\hline 9. & The school principal always asked for lesson plan notebook. & 2.56 & Disagree & 2.33 & Disagree \\
\hline 10. & $\begin{array}{l}\text { My academic supervisor used to suggest solutions to my } \\
\text { problems }\end{array}$ & 3.67 & Agree & 3.40 & Neutral \\
\hline 11. & $\begin{array}{l}\text { 1was encouraged to ask questions that could help me develop } \\
\text { my various skills }\end{array}$ & 3.53 & Neutral & 2.93 & Neutral \\
\hline 12. & $\begin{array}{l}\text { The cooperating teacher facilitated the teaching process and } \\
\text { made it fun for me. }\end{array}$ & 3.02 & Neutral & 2.87 & Neutral \\
\hline 13. & $\begin{array}{l}\text { The method of evaluating my skills in the Practicum was fair } \\
\text { and appropriate }\end{array}$ & 4.42 & S. agree & 4.27 & S. agree \\
\hline 14. & $\begin{array}{l}\text { Feedback of my cooperating teacher was very helpful during } \\
\text { Practicum }\end{array}$ & 2.84 & Neutral & 2.93 & Neutral \\
\hline \multicolumn{2}{|r|}{ General Mean } & 3.145 & Neutral & 2.904 & Neutral \\
\hline
\end{tabular}

Table 11. T. Test for the difference between students of high and low accumulative averages in accordance to Practicum barriers

\begin{tabular}{|c|c|c|c|c|c|c|}
\hline Group & N & M & SD & Mean Difference & T. Ratio & Sig. \\
\hline High average students & 43 & 3.1450 & 0.53281 & 0.2407 & 1.178 & 0.844 \\
\hline Low average students & 15 & 2.9043 & 0.54874 & & & \\
\hline
\end{tabular}




\section{Discussion}

\subsection{Discussion of the Findings of the First Question}

An analysis of the collected data has shown that most participants were satisfied with the benefits Practicum offered to them during their field experience. Their agreement levels ranged between "strongly agree and agree". This, of course reflects the fact that Practicum was very effective in providing trainees with certain ideas that could modify their work as teacher trainees. Practicum has mainly developed student teachers' supportive relationships with various participants in the Practicum setting; their successful teaching accomplishments and professional achievements; and their feelings of self-efficacy in being able to affect positively the students under their care. This finding corroborates what [23] has concluded regarding the main positive themes of Practicum. Furthermore, findings of the present study assert student teachers' needs, as mentioned by [24], regarding the reception of their cooperating teachers' emotional support, collaboration, and peer relationship with them; flexibility in teaching content and method, frequent feedback on their performance, and the identification of a sound approach to teaching and learning inside classrooms were also enhanced. Participants' responses emphasized the fact that their Practicum was very beneficial and fruitful. Their high level of agreement indicates that most of their needs for the teaching experience were fulfilled and this conclusion is congruent with the definition of Practicum presented by the [25] providing students with the opportunity to explore new areas and to enhance their professional skills and knowledge. In addition, findings also support what [5] revealed in accordance to student teachers' improvement in preparing, conducting, post-processing lessons, general teaching skills, attitudes towards students, and self-esteem. Developing student teachers' self-esteem was another issue that could make Practicum successful and essential for students who will someday join teaching profession. [19] mentions that apart from affecting student teachers' way of teaching, self-esteem also affects the way they interpret and learn from the "Practicum", their ability to cope, and interact effectively with adults and children. Furthermore, findings are in agreement with the findings of [26] which stated that learning to teach is an emotional and complex social process of negotiation. Through Practicum, students learn how to manage their behavior, plan their lessons, and deliver their curriculum. Findings related to the positive influence of mentors, supervisors, and other school staffs confirm the results of [16] which concluded that student teachers develop their understanding of professional learning in light of their experiences of engaging with others during Practicum.

\subsection{Discussion of the Findings of the Second Question}

Analyses of participants' responses confirmed that there were negative aspects, which they wished to be controlled before and during their field experience at schools as trainees.
These points can be categorized into three or more sources namely, school principals, cooperating teachers, academic supervisors, and teacher preparation programs. Student teachers mentioned that most of their school principals did not follow up their daily lesson preparation, which in turn was reflected in their ability to distinguish correct from incorrect procedures and ways of teaching. That is, the school principal as a person of expertise was not of benefit for them. Most of participants' responses revealed training weakness to show them how to use teaching aids in the classroom. They also revealed the ineffectiveness of the many courses they learnt at university in qualifying them for teaching profession. Carelessness of their cooperating teachers increased their sufferings while teaching. Most of those teachers were not collaborative, unavailable when needed, and lack the ways of feedback provision and commenting on trainees' performance. One more source of participant students' weak performance was the shortage of orientation by their academic supervisors that affected the immediate solutions for various teaching problems they faced. These barriers or difficulties corroborate the findings of [10] regarding the various parties to help in teaching techniques, feedback provision and guidance in co-curricular activities. They also emphasize the results of [11] and [12] with regard to trainees' provision with teaching model lessons and school principals' lack of follow up student teachers' work follow-up. These results also assert the results by [4] and [14] in relation to the variance between theory at university and practice at schools. They also support the findings of [2] in accordance to the responsibility of supervisors, cooperating teachers, and school principals to correct trainees' mistaken or wrong beliefs about the teaching practice.

\subsection{Discussion of the Findings due to Gender and University Accumulative Average}

Findings showed no statistically significant differences among student teachers' perspectives with regard to the opportunities, which Practicum provided them or to the barriers that constrained their teaching performance. Participants' gender and accumulative average had made no differences between their views. Such a result can be explained by a set of factors among which was their social and educational background. All participants, whether male or female, came from nearly the same families. They were brothers, sisters, cousins or even relatives. Even if they were not so, they were living in families that hold approximately similar thinking and culture. Furthermore, their educational backgrounds were also similar. Most of them had received their study from grade one to grade twelve at schools that were similar in every aspects, the curricula, textbooks, teachers, and furnishing. Later on, they joined the university and were subjected to the same level of teaching and teachers. Therefore, it was not strange to have similar perspectives despite their gender or university average. These results corroborate the idea of [22] about earning processes that 
occur through experiences in the social practices associated with particular activities. They also support the findings of [9] regarding certain variables such as participants' gender and academic levels.

\section{Conclusion}

The study investigated the perspectives of student teachers who were enrolled in Practicum course for English specialty students at Najran University with regard to the opportunities it provided them with. In addition, it studied the barriers that could inhibit their field experience and deprive them from being successful teachers as expected. Results showed that such course was effective in certain areas such as developing their supportive relationships with various participants in the Practicum setting; their successful teaching accomplishments and professional achievements; and their feelings of self-efficacy in being able to affect positively the students under their care. On the other hand, participants' responses indicated many shortcomings or obstacles that hindered their performance as teaching practitioners. These shortcomings were not related to one specific part but many parts such as academic supervisors, school principals, and cooperating teachers. No significant differences among their perspectives regarding the course's opportunities or barriers were found due to their gender and/or university accumulative average. Therefore, it can be concluded that people in charge of the implementation of Practicum courses are called for looking for and solving the prospect and probable difficulties before sending student teachers to schools for their teaching practice. They are also required to foster opportunities offered by Practicum courses and facilitate trainees' work at school through intensive visits and interviews to stimulate the good and exclude the bad actions.

\section{Acknowledgment}

The researcher is indebted to the Deanship of Scientific Research at Najran University for funding this research that holds decision number (NU/SHED/15/147) and for every possible help they offered.

\section{REFERENCES}

[1] Hamaidi, D.; Al- Shara, I; Arouri, Y.; Abu Awwad. F. Student Teachers' Perspectives of Practicum Practices and Challenges, European Scientific Journal. (2014); 10 (13)

[2] Ong'ondo, C. O. \& Jwan, J. O. Research on Student Teacher Learning, Collaboration and Supervision during the Practicum: A Literature Review, Educational Research and Review. (2009); 4 (11): 515 - 524. Retrieved from http://www.academicjournals.org/article/article1379617229 Ong'ondo\%20and\%20Jwan.pdf
[3] Leshem, S. \& Bar-Hama, R. Evaluating Teaching Practice, ELT Journal. (2008); 62 (3): 257-265.

[4] Dweikat, K. A. Attitudes of TEFL Student Teachers at QOU towards the Implementation of Practicum, Al-Quds Open University Journal for Educational \& Psychological Research \& Studies. (2013); 1 (3).

[5] Hascher, T.; Cocard, Y. \& Moser, P. Forget about TheoryPractice is All? Student Teachers' Learning in Practicum, Teachers and Teaching: theory and practice. (2004); 10 (6), DOI: $10.1080 / 1354060042000304800$ Retrieved from http://www.tandfonline.com/doi/abs/10.1080/1354060042000 304800? needAccess $=$ true $\&$ journalCode $=$ ctat 20

[6] Selvi, A. F. (2012). A Quest to Prepare All English Language Teachers for Diverse Teaching Settings: If Not Us, Who? If not Now, When? (Ph. D Dissertation), University of Maryland, College Park, UMI Dissertation Publishing, UMI 3557690

[7] Wambugu, P.; Barmao, A.; \& Ng'eno, J. Student Teachers' Teaching Practice Assessment in Egerton University, Kenya, Education Journal. (2013); 2 (4): 169-175. Retrieved from: $\mathrm{http}: / /$ article.sciencepublishinggroup.com/pdf/10.11648.j.edu. 20130204.20.pdf

[8] Franke, A. \& Dahlgren, L.O. Conceptions of mentoring: an empirical study of conceptions of mentoring during the school-based teacher education. Teaching and Teacher Education. (1996); 12 (6): 627-641. Retrieved from http://www.sciencedirect.com/science/article/pii/S0742051X 96000042

[9] Koç, E. M. (2011). Factors Affecting Student Teachers' Perceptions on Mentor Roles: A Study at Distance English Language Teacher Training Program, TOJET. (2011); 10 (1). Retrieved from:

http://www.tojet.net/articles/v10i1/10112.pdf

[10] Akhtar, R. N.; Abdul Majeed \& Murtaza, A. The Role of Collaborating Teachers (CTs) in Facilitating Prospective Teachers (PTs) in Lesson Delivery: A Multi-Case Study of Teaching Practicum, Bulletin of Education and Research. (2013); 35 (2): 107-124.

Retrieved from http://www.pu.edu.pk/images/journal/ier/PDF -FILES/007\%20Raja\%20Naseem\%20Akhtar_Abdul\%20Maj eed Ali\%20Murtaza\%20107-124.pdf

[11] Al-Magableh, A. M. F. (2010). An Evaluation of English Practicum at Yarmouk University from Cooperative Teachers and Student-Teachers' Perspectives, International Journal of Language Studies (IJLS). (2010); 4 (4): 19-56. Retrieved from http://web.b.ebscohost.com/ehost/pdfviewer/pdfviewer?vid=1 $\&$ sid $=6233$ c327-beca-4451-9433-eebb98fb69a8\%40sessionm gr104

[12] Merç, A. (2015). Assessing the Performance in EFL Teaching Practicum: Student Teachers' Views, International Journal of Higher Education. (2015); 4 (2). Retrieved from: http://www.sciedu.ca/journal/index.php/ijhe/article/view/641 $6 / 3889$

[13] Volante, L. (2006). Essential Elements in Teacher Education: Preservice Student Perspectives, The Alberta Journal of Educational Research. (2006); 52 (2): 167-180. Retrieved from:

http://ajer.journalhosting.ucalgary.ca/index.php/ajer/article/vi ew/530/519 
[14] Ronsyn, K. M. (2013). Exploring the Relationship of Associate Teachers and Teacher Candidates within the Teaching Program, (Ph. D. Dissertation), University of Toronto. Published by ProQuest LLC (2014). Retrieved from: https://tspace.library.utoronto.ca/bitstream/1807/43711/3/Ron syn_Kathleen_201311_PhD_thesis..pdf

[15] Sussbauer, E. J. (2013). Building a Third Space: How Academic Language Knowledge Helps Pre-Service Teachers Develop Content Literacy Practices, (Ph. D. Dissertation), University of Massachusetts at Amherst. Retrieved from: http://scholarworks.umass.edu/cgi/viewcontent.cgi?article=17 70\&context $=$ open_access_dissertations

[16] Gan, Z. (2014). Learning from Interpersonal Interactions during the "Practicum": A Case Study of Non-Native ESL Student Teachers. Journal of Education for Teaching: International Research and Pedagogy. (2014); 40 (2): 128-139. DOI: 10.1080/02607476.2013.869969 retrieved from

http://www.tandfonline.com/doi/abs/10.1080/02607476.2013. 869969

[17] Jusoh, Z. Teaching "Practicum": Student Teachers' Perspectives, $3^{\text {rd }}$ International Conference on Foreign Language learning and Teaching, FLLT Conference Proceedings by LITU. (2013); 2 (1). Retrieved from: http:/www.litu.tu.ac.th/journal/FLLTCP/Proceeding/865.pdf

[18] Kelly, S. \& Tannehill, D. The Mentoring Experiences of an Irish Student Teacher on his Physical Education Teaching Practicum. Graduate Journal of Sport, Exercise \& Physical Education Research. (2012); 1: 47-64. Retrieved from http:/www.worcester.ac.uk/gjseper/documents/The_mentorin g_experiences_of_an_Irish_student teacher_on_his_physical _education_teaching_practicum_2012_1_47-64.pdf

[19] Dobbins, R. Student Teacher Self-Esteem in the Practicum. Australian Journal of Teacher Education. (1996); 21(2). DOI:10.14221/ajte.1996v21n2.2

Retrieved from http://ro.ecu.edu.au/ajte/vol21/iss2/2/
[20] Fortune, A. E. (1994). Field Education. In F. J. Reamer (eds.), The Foundations of Social Work Knowledge. New York: Columbia University Press.

[21] Bogo, M.; Regehr, C.; Power, R.; Judy Hughes, J.; Michael Woodford, M.; \& Regehr, G. Toward New Approaches for Evaluating Student Field Performance: Tapping the Implicit Criteria Used by Experienced Field Instructors, Journal of Social Work Education. (2004); 40 (3): 417-426. Retrieved from:

https://www.jstor.org/stable/23043992?seq=1\#page_scan_tab contents

[22] Johnson, K. E. The Sociocultural Turn and its Challenges for Second Language Teacher Education. TESOL Quarterly. (2006); 40 (1): 235-257. Retrieved from: http://www.scu.edu .tw/english/2008/people/wei_da/1229the_sociocultural turn and_its_challenges_for_2nd_lg_teacher_ed.pdf

[23] Ralph, E., Walker, K. \& Wimmer, R. The Practicum in Professional Education: Pre-Service Students' Experiences, Teaching \& Learning Journal. (2007); 1 (2). Retrieved from:http://www.kpu.ca/sites/default/files/Teaching\%20and \%20Learning/TD.1.2_Ralph_Practicum_Professional_Educat ion.pdf

[24] Beek, C. \& Kosnik, C. (2002). Components of a Good Practicum Placement: Student Teacher Perceptions, Teacher Education Quarterly. (2002); 81-98. Retrieved from: http://www.teqjournal.org/backvols/2002/29_2/sp02beck_kos nick.pdf

[25] Rollins School of Public Health, (2014). Practicum Handbook: A Guide for Students, Rollins School of Public Health: Emory University. E book, Retrieved from http://docplayer.net/4495422-Practicum-handbook-a-guide-fo r-students.html

[26] Pinder, H. (2008). Navigating the Practicum: Student teacher perspectives on their learning, Paper presented at the British Educational Research Association Annual Conference (BERA), Heriot-Watt University, Edinburgh, 3-6 September 2008 